Meta

Journal des traducteurs

Translators' Journal

\title{
How to Become a Patent Translator: Tricks and Tips - Notions of Text Genre and Ceremony to the Rescue
}

\section{Maite Aragonés Lumeras}

Volume 55, numéro 2, juin 2010

URI : https://id.erudit.org/iderudit/044236ar

DOI : https://doi.org/10.7202/044236ar

Aller au sommaire du numéro

\section{Éditeur(s)}

Les Presses de l'Université de Montréal

ISSN

0026-0452 (imprimé)

1492-1421 (numérique)

Découvrir la revue

Citer cet article

Aragonés Lumeras, M. (2010). How to Become a Patent Translator: Tricks and Tips - Notions of Text Genre and Ceremony to the Rescue. Meta, 55(2), 212-236. https://doi.org/10.7202/044236ar
Résumé de l'article

Avant d'entreprendre la traduction de brevets et d'abrégés de brevets, les traducteurs, qui ne peuvent se dire experts d'un domaine spécifique, doivent tenir compte du contexte de production des genres textuels ainsi que des intentions communicatives, afin de s'assurer que le sens est rendu de façon acceptable (compte tenu de la cérémonie), de façon à ne choquer personne ni dénaturer l'objectif de l'auteur. Le présent article fait état des résultats d'une étude dans laquelle ont été analysées les séquences rhétoriques (moves) des abrégés de brevets dans quatre langues (chinois, espagnol, français et anglais) et dans quatre domaines (médecine, chimie, télécommunications et informatique), ainsi que la valeur rhétorique des choix linguistiques (par ex. : modalité, temps verbaux, voix passive, adverbes et adjectifs). La méthodologie déployée est double : qualitative, pour expliquer le contexte de production des textes selon certains paramètres en rapport avec le genre et offrir une interprétation des résultats quantitatifs ; quantitative, pour appliquer l'analyse linguistique aux abrégés de brevets. L'échantillonnage de textes se fonde sur des critères de date de publication, de langue originale et de discipline, et a permis de constituer un corpus de 200 textes. Les résultats semblent indiquer, d'une part, que la discipline ne joue pas un rôle considérable dans les choix linguistiques des rédacteurs et, d'autre part, que l'intensification et l'atténuation sont toutes deux des procédés rhétoriques visant à combiner intentions privées et finalités collectives, afin de satisfaire les exigences institutionnelles et les attentes des destinataires.
Ce document est protégé par la loi sur le droit d'auteur. L'utilisation des services d'Érudit (y compris la reproduction) est assujettie à sa politique d'utilisation que vous pouvez consulter en ligne.

https://apropos.erudit.org/fr/usagers/politique-dutilisation/ 


\title{
How to Become a Patent Translator: Tricks and Tips - Notions of Text Genre and Ceremony to the Rescue
}

\author{
MAITE ARAgONÉS LUMERAS \\ World Intellectual Property Organization, Geneva, Switzerland \\ maite.aragones-lumeras@wipo.int
}

\section{RÉSUMÉ}

Avant d'entreprendre la traduction de brevets et d'abrégés de brevets, les traducteurs, qui ne peuvent se dire experts d'un domaine spécifique, doivent tenir compte du contexte de production des genres textuels ainsi que des intentions communicatives, afin de s'assurer que le sens est rendu de façon acceptable (compte tenu de la cérémonie), de façon à ne choquer personne ni dénaturer l'objectif de l'auteur. Le présent article fait état des résultats d'une étude dans laquelle ont été analysées les séquences rhétoriques (moves) des abrégés de brevets dans quatre langues (chinois, espagnol, français et anglais) et dans quatre domaines (médecine, chimie, télécommunications et informatique), ainsi que la valeur rhétorique des choix linguistiques (par ex.: modalité, temps verbaux, voix passive, adverbes et adjectifs). La méthodologie déployée est double: qualitative, pour expliquer le contexte de production des textes selon certains paramètres en rapport avec le genre et offrir une interprétation des résultats quantitatifs; quantitative, pour appliquer l'analyse linguistique aux abrégés de brevets. L'échantillonnage de textes se fonde sur des critères de date de publication, de langue originale et de discipline, et a permis de constituer un corpus de 200 textes. Les résultats semblent indiquer, d'une part, que la discipline ne joue pas un rôle considérable dans les choix linguistiques des rédacteurs et, d'autre part, que l'intensification et l'atténuation sont toutes deux des procédés rhétoriques visant à combiner intentions privées et finalités collectives, afin de satisfaire les exigences institutionnelles et les attentes des destinataires.

\section{ABSTRACT}

Before starting to translate patents and patent abstracts, translators - who are not discipline experts - need to be aware of the context of text genre production and the communicative purposes and intentions to make sure they are conveying the intended meaning in the accepted manner (of the typical ceremony) in order not to shock the recipient and distort the author's original intent. This article aims to present the results of a study that analyzes both the moves of original patent abstracts in four languages (Chinese, Spanish, French and English) and four disciplines (medicine, chemistry, telecommunications, and IT) and the rhetorical value of linguistic choices (i.e., modality, verb tense, passive voice, adverbs and adjectives). The methodology used is twofold: qualitative so as to explain the text production context according to certain parameters related to text genre and give a better interpretation to the quantitative results, and quantitative so as to conduct a linguistic analysis of the patent abstracts. Text samples were chosen according to date of publication, original language and discipline, and form a corpus of 200 texts. The results appear to show that discipline does not play a major role in the linguistic choices made by the abstractors, and that boosting and hedging are both rhetorical ways to combine private intentions and collective purposes, while satisfying institutional requirements and recipients' expectations. 


\section{MOTS-CLÉS/KEYWORDS}

abrégé de brevet, finalités communicatives, intentions, cérémonie, séquences rhétoriques patent abstract, communicative purposes, intentions, ceremony, rhetoric moves

Scientists do not simply "let the facts speak for themselves," but must constantly appraise and reappraise the rhetorical situation in which they are writing. They must fashion their claims and choose their words carefully [...] Moreover, to be successful, writers must draw upon a repertoire of rhetorical strategies to steer a course between presenting original claims and securing their readers' consensus that a claim is acceptable as well as novel. Not only must writers use various rhetorical and linguistic devices in order to negotiate with their readers, but they must also possess a thorough familiarity with the conventions of writing in their subspecialty, so that they can use these conventions to their best advantage.

(Berkenkotter, Huckin and Ackerman 1989: 3)

\section{Introduction}

Although translation is one of the oldest professions in the world, there is still a lack of consensus on defining the process and hence establishing a modus operandi. For a long time, translation has been limited to a linguistic exercise based on static, dynamic, and functional equivalences (this is the case for the translation of the Bible, legal translation, specialized translation that pays particular attention to terminology, etc.). The specificity of religious texts and legal documents has been, in a sense, responsible for a literal approach to translation, i.e., every word was to be translated in the target language to make sure the translation was reliable and close to the meaning (Aragonés Lumeras 2008a). Meaning ${ }^{1}$ has then become the unit of measure for the translator, who should always be neutral and objective.

In our opinion, meaning is neither objective nor universal; it is the crossroads of the six extra-textual parameters, that is, ceremony-conventions, institutions-communicative purposes, participants-intentions, that have first been established (Aragonés Lumeras 2009) for analyzing the qualitative world of patent abstracts, and might be used for any genre. These three pairs of extra-textual parameters have been used since 2007 as the basic elements of our translation method when teaching students in patent translation and general translation, because they help professional translators as well as students understand why a writer decides to draft a text and to 'speak to a specific audience.' To understand meaning, we first need to notice and grasp the author's intentions and the communicative purposes of the community to which the author belongs, and to identify the ceremony and the participants. A text cannot be understood on its own, it only makes sense in a specific situation. This is why readers have to deal with meanings and interpret a text in a specific text production context. Meanings can only be understood in situation, but situations can vary. For instance, the remark "it is cold in here" can be an implicit invitation to close an opened window, a criticism to a stingy person, or a proposal to turn the heating on. Let's turn now to the world of patents and have a look at what happens with the above mentioned clichés, i.e., static, dynamic or functional equivalences and the notion of meaning.

Meaning has always been a human inescapable need; it is therefore a human subjective construct that may be labeled as versatile because it is referential, seman- 
tic, contextual, and pragmatic. As explained previously, several meanings can be extracted from a same text depending on the period of time, on the recipient, on the reader's background, on the field of knowledge, and other factors. Meaning is not therefore a valid unit for measuring what has been understood, and it evolves dynamically over time. A text does not enclose one content, one message, but is an imperfect framework of intentions and purposes expressed in specific formal conventions. It is the crossroads of the six extra-textual parameters and broadens the spectrum of interpretations that might be right, wrong or partially right and partially wrong according to particular circumstances. The limits between what is meant and what is actually written, and the limits between what should be understood and what is actually understood are totally and selectively permeable.

On one hand, inventors, patent applicants, examiners, patent attorneys and translators take part in a ceremony (Freadman 1994). This concept used by Freadman - who is a representative of the New Rhetoric School (also known as North-American School) - in her article "Anyone for Tennis?" is very convenient because it reminds writers (and thereby translators) that there are always rules to follow when dealing with communication. This social concept has been adopted because we are convinced, and our current experience in teaching translation at ETI (École de Traduction et d'Interprétation) and UJI (Universitat Jaume I) supports this thought, that translators cannot understand and interpret a text without knowing the 'big picture.' For instance, if someone is invited to participate at a social event (ceremony) without knowing which particular event (text genre) it will be very difficult to decide what to wear (appropriate terms and expressions, technical terms, formal conventions, and so forth). The same happens with translation. How can translators choose the appropriate term or expression, or make convenient linguistic choices, if they do not know the circumstances of text production, the objectives pursued by the writer, the information brief (Nord 1997), and the private intentions?

Ceremony (Aragonés Lumeras 2008b, c, 2009) is a social activity performed on a special occasion recognizable by insiders (the members of the socio-professional community), and an unofficial, but formal communicative act. The text, raw material for the translator, is the written materialization of a social event and becomes then a medium for transmitting knowledge, a socially constructed platform, an institutionalized medium, and a global communicative unit, instead of merely being a linguistic form. The ceremony may indicate that a specific event, irrespective of language, time or field, is recurrent and has to be performed in a conventional way. This social peculiarity is one of the characteristics of the socio-communicative act performed by members of a specific socio-professional group and may be assimilated to 'idiosyncrasy' (Reed 2008). In a symbolic approach, the meaning vectored in a ceremony relies on conventions (Aragonés Lumeras 2007b, 2008b, c and 2009), which may eliminate the arbitrary semantics of words, and moves away from the static values of precision, clarity, objectivity and neutrality.

On the other hand, the patent system is based on a trans-disciplinary view of communication. Moving away from the traditional classification of knowledge based on subject matter and thematic items, the patent world involves various socio-professional communities, e.g., engineers, physicians, doctors, oil companies, industries, and patent attorneys. There appears to be a need to organize knowledge in a way differing from the UNESCO classification and the IPC (International Patent 
Classification) for the sake of translators, who are not specialists in a discipline, but specialize in the patent application ceremony. Therefore, it is convenient to highlight the fact that a translator cannot turn down a patent translation job arguing that she/he is not specialized in a specific subject matter - contrary to substantive examiners (at patent offices) who deal only with patents related to their field of specialization. Translators will have to go into patents in depth to learn how to draft one properly and comply with formal patent conventions. In fact, the translation labor market establishes the rules for translators and forces translators to become patent experts, that is to say genre experts. Texts - that share common micro- and macrocharacteristics, i.e., formal conventions, moves, and rhetorical function - pertain to a specific text genre, which makes them recognizable for insiders, but not for translators, who are outsiders.

There is a real need to achieve the goal of widening translators' awareness of what is at stake in the communicative event before translating a text, because a text only makes sense within a context and is subject to being interpreted in different ways according to a myriad of factors.

L'autonomie n'est pas autarcie, et le texte ne prend sens que pour un lecteur dans un contexte. D'où le rejet d'un principe d'immanence, qui voudrait que «tout» soit «dans » le texte. La lecture est une actualisation [...] Le texte, coupé de toute réalité, ne peut se situer et prendre sens. (Bommier-Pincemin 1999: 142)

The current situation in Translation Studies urgently needs to find a way to conceal different studies so as to unify conclusions and work together toward a global translation theory based on descriptive and experimental studies. In an attempt to reply to Toury (1995), who deplores the lack of methodology in Translation Studies, a descriptive multilingual study of patent abstracts has been undertaken. There is an urgent need for a systematic examination of Translation Studies, to depart from intuition, and use clear methodology techniques in order to ensure that the findings and conclusions are testable and replicable. In other words, Translation Studies should be based on a more rigorous research methodology.

\section{Genre: Revealing Socio-Communicative Purposes and Private Intentions}

The starting point of this article will be text genre because it helps to:
a) classify texts;
b) contextualize texts and go beyond linguistic aspects;
c) make text characteristics recognizable;
d) identify communicative purposes;
e) be part of the communicative event as an insider;
f) understand participants' motivations and intentions;
g) get the 'big picture' and become familiar with specific habits;
f) read the original text and reformulate the new text (TT); and
g) assist the translator in making decisions.

Text genre is a notion that has gained greater recognition in LSP (Language for Specific Purposes). Bhatia (2000) and Swales (1990), going against the trend, insist on the fact that discipline is not a significant factor when drafting texts, and we fully agree with them, as the results of our investigation suggest. In Europe, terminology 
has gained ground in specialized translation and has influenced text analysis reducing it to a word combination search. This situation together with the traditional way of fragmenting translation job has led translators and scholars to focus on disciplines considered as the best solution to specialized translation problems.

Genres are platforms for discourse communities, which do not always pertain to the same socio-professional group, as is the case for patents, instructions, abstracts, research articles, reports, contracts, and so forth. However, - if the reader allows me to digress briefly - Gentt ${ }^{2}$ (Text Genre for Translation) team has favored the use of discipline as primary criteria for classifying genres because this approach is closer to the traditional approach in translation schools where classes are organized according to disciplines such as law, economics, sciences, etc., and they have adopted a socio-professional perspective for delimiting the reality of genre. It is not the purpose of this investigation to discuss this problem, which will be discussed in a future work. A common ground is that genre is more than a linguistic category for organizing texts; it is a signpost used to impose a rule of conduct, which, if transgressed, hinders interaction. Genre is the translator's GPS when traveling across a text and trying to find out what are the real motivations. Genre is an interface that participants, involved in a specific ceremony, recognize and handle in order to achieve collective and private goals. It becomes a very useful tool for translators who need to understand the pros and cons of communicative acts. Their linguistic choices will then be affected by the text macrostructure (called 'move' by Swales 1990) and the conventional rhetorical aspects of modality, verb tense, passive and active voice, adverbs and adjectives, and so on in order to boost or hedge the discourse.

The importance of recognizing text genres is considered by Sager to be paramount in the diagnosis of contextual information, namely for identifying intention:

In order to carry out the task of information mediators, translators need unambiguous means of identifying intention and, equally important, means of expressing it. The most visible means of expressing intentions is through the choice of conventional text types. Text types have evolved as patterns of messages for specific communicative situations. When we write a message we first think of the text type that is suitable for the occasion and the content, and formulate our text accordingly. (Sager 1997: 30)

It is to be said here that some scholars use 'text type' for 'text genre.' This may lead to a certain confusion, and should be clarified. Translators seem to sometimes resist changing, and prefer to keep using 'text type'; one of the reasons might be that they are not completely ready to move toward a new theory that will lead to a change in their day-to-day practice.

Text genre is also a very important concept for translators because our perspective on specialized translation deviates from the common view that considers specialized translation as a process of finding technical term equivalences according to the subject field. Text genre dethrones terminology because discipline or technical field is not a predominant factor - to be kept in mind - for a professional translator or a student, as shown by our research. Even if numerous socio-professional communities, such as physicians, mechanical engineers, biologists, architects, petrol industry researchers, chemists, doctors, and so on play a sizeable part in the patent or patent abstract drafting, discipline is not a decisive factor when making linguistic choices during the translation process for a simple reason: text genre imposes its own conventions and influences the patent or patent abstract drafting. Genres are outside the 
boundaries of a particular socio-professional activity. When Berkenkotter and Huckin (1995) strive to teach students in technical fields the ability to write, they do not take an interest in technical terms (perhaps because they are used to the lexical elements), but on rhetorical strategies used in each genre to persuade readers that what is claimed is new and real. When answering the question how to transmit knowledge on genre, they explain:

This knowledge, rather than being explicitly taught, is transmitted through enculturation as apprentices become socialized to the ways of speaking in particular disciplinary communities. (Berkenkotter and Huckin 1995: 7)

Our experience as a translator has highlighted the importance of understanding the implicitness of a text. When communicating, people often hush up their real intentions for different reasons, namely to be polite, to avoid any commitment, to persuade the reader of their honesty, to avoid being too straightforward, to give a good image, and so forth. There is consensus on the fact that a translator has to deal with different 'mandates': to be faithful to the author, to satisfy recipients' expectations, but at the same time to conform to the translation initiator (Skopos and Functionalism). It may happen that the translator is in an awkward position, and she/he will have to take a position. Translating is a process in which making decisions is the corner stone, the problem being to have sufficient information on the communicative act, institution purposes, and participants' intentions. This is where the Genre Theory comes in and helps give an overview of what is happening behind the scenes.

Scientific, technical, legal, medical writers have been taught how to choose the proper genre in order to achieve their communicative purposes, why shouldn't translators, who act as if they are writers (Aragonés Lumeras 2007a, b), be aware of text genres? A scientific article has no common ground with a contract, even if it deals with the same subject matter, and knowing this makes the drafting process easier. The findings of previous research have shown that part of the translation problems are related to textual conventions, i.e., even the selection of technical terms in patents depends on the conventions. For this reason the patent translator must become familiar with patent drafting in the target language to make sure she/he will use proper expressions, such as, 'in a preferred embodiment,' 'for example, but not limited to,' 'in use,' and so on. The translator should not invent a literal translation or give explanations, but find out through texts pertaining to the same genre in the target language what it the usual expression. A glossary of patent conventions may be very useful for translators (Aragonés Lumeras 2008b).

Extensive reflection on what translation is has led us to give a new definition of translation taking into account new elements, namely six extra-textual parameters, as well as the notion of reading and drafting. Translating implies then a reading competence, a genre competence, a writing competence, a context analysis competence, and an awareness of the relevance of rhetorical effects that might change according to language. In order to delimit the infinite possible interpretations of a text in its context, the six extra-textual parameters are useful tools that reduce the possible readings the translator might have.

A translator must play the part of a detective to assess any information or any clue (micro-linguistic level and contextual level), however insignificant it may be, 
before acting as an actor, and pretending to be the writer. This is the reason why she/he is expected to be as neutral as possible, even if it is impossible in practice. The most difficult to achieve is to make the most appropriate linguistic decisions that adhere to the author's intentions, but at the same time comply with the institutional requirements using the formal conventions. In the specific case of patent abstracts, the writer has to draft a short text that describes the invention so as to give the reader the gist of the patent document, insisting on the novelty, but not fully disclosing the invention so as to keep the legal protection and avoid copying by third parties. That can happen all too easily, and is exactly what the translator must be aware of and guard against in handling outwardly incompatible purposes.

\section{The Multiple Rhetorical Functions of Micro-linguistic Elements: Translator Awareness}

Communication is, first of all, interaction with others in a specific situation so as to share views and new information. For a member of a specific community, persuasion is the final aim of any communication. As Aristotle wrote, to be efficient and persuasive, a lawyer has to address the judge in a friendly ${ }^{3}$ manner in order not to offend her/him. The results of different studies undertaken by Salager-Meyer (1994), Vihla (1999), Hyland and Milton (1999), and Varttala (2001) related to rhetorical functions in technical genres hint that hedging is a common way to keep a certain distance between the author and the recipient of a text. Hedges play, then, the role of downtoners aimed at mediating between two persons; politeness, lack of commitment to the truth (supposed objectivity), and vagueness are the best ways to convince without generating conflict. In addition, other studies set out that boosters are not so common (Oliver del Olmo 2004) arguing that they are emotionally charged and are, therefore, not common in technical genres, which are considered to be neutral and objective.

We do not share this point of view as the numerical data derived from our descriptive study show that boosters, as well as hedges, constitute rhetorical devices for modulating tone in the patent abstract genre. This assertion has been supported by an investigation (Aragonés Lumeras 2007b) that showed that patents and patent abstracts use boosters, as well as hedgers, to provide the information on the novelty so as to insist on the advantages without aggressing the reader. Actually, Chinese and Spanish patent abstracts are prone to use a discourse much closer to advertising and promotional genres than to technical genres. Nobody will blame patent drafters for this surprising 'style,' even if outsiders (i.e., translators) are so impressed by technical terms that they do not pay due attention to the conventions and the astonishing rhetorical devices employed in patents and patent abstracts. Verb tenses, negation, modality, emphasizing adverbs and adjectives have a rhetorical effect that boost the discourse contrary to popular belief. Here are a few examples ${ }^{4}$ taken from the patent abstract corpus that illustrate what the present discussion here and clearly show that boosters are commonly used in patent abstracts whatever the language and the discipline:

- 完全克服了晶体层状生长习性 (CN14) completely overcomes the layering growth tendency

- 在有限的系统资源下, 使更多的用户更好地获得所需的服务, 能高效、合理地利用系 统资源的目的。(CN22)

With the limited system resource, a larger number of users can get the required 
services in better conditions by using system resource more efficiently and conveniently.

- 本发明将滑板和自行车的功能集于一体, 既能作行驶工具, 又能娱乐健身, 特别适 合于极限运动的爱好者。(CN50)

The present invention combines both the functions of scooters and bicycles, while it contributes to making sport and recreation, and is particularly suitable for amateurs of extreme sports,

- lo que les confiere el potencial de penetrar mejor los tejidos in vivo y de ser menos inmunogénicos en el hombre. (ES5)

- Los nuevos compuestos presentan actividad vasodilatadora e inhibidora de la agregación de las plaquetas, lo que los hace útiles para el tratamiento de disfunciones del sistema circulatorio, especialmente a nivel cardiovascular. (ES19)

- Una llamada telefónica efectuada por Internet con Protocolo IP con un teledatáfono permite hablar todo el tiempo que se desee, sin ningún costo adicional de pulsos telefónicos. Con la cuota mensual del acceso a Internet de Banda Ancha que ofrece un proveedor de acceso a Internet (ISP), cualquier usuario podrá hablar $\mathbf{2 4}$ horas por día, 30 días al mes, y, simultáneamente, navegar por Internet desde su computadora o red de computadoras.(ES29)

- Lacétate de cyprotérone est donc une alternative intéressante aux psychotropes sédatifs chez les patients ayant une démence dégénérative ou vasculaire avec agressivité et/ou impulsivité. (FR6)

- Ainsi les divisions cellulaires à partir de ce noyau rajeuni se feront dans un cytoplasme autologue et adulte et les cellules qui en résultent seront immédiatement adultes, différentiées et fonctionnelles. Le tissu autologue rajeuni ainsi crée pourra être greffé sans rejet au niveau du tissu adulte de l'organisme de provenance du noyau traité. (FR 10)

- Avec ces éléments on peut exécuter la totalité du gros oeuvre d'un bâtiment. La composition possède à la fois des propriétés de résistances mécaniques, d'isolation thermique et phoniques. (FR42)

- Applicants have discovered that a particular bacteriocin from the vaginal strain of Lactobacillus rhamnosus, lactocin (160), possesses a particularly advantageous activity against microorganisms associated with vaginal infections, and more specifically those associated with Bacterial Vaginosis (BV). (EN 7)

- In certain embodiments, the film structures may exhibit optical clarity, tack, sealability, toughness, softness, and machinability properties superior to conventional polypropylene films and other conventional polyolefin films. (EN19)

- Those skilled in the art will appreciate that the analysis of a particular component may comprise certain tests and/or evaluations. (EN 36)

Regardless of the discipline and language, the examples indicate that boosters are a rhetorical means for describing the characteristics of the invention that can be compared to the rhetorical devices used in advertising. This draws attention to the fact that text type cannot be only descriptive, but mingles, in the case of patents, with argumentation and persuasion. The private intentions will be brought to light, thus improving the translator's reading ability. It must be therefore recognized that when writing nothing happens by accident, quite the contrary, communication is intentional and may move away from the pursued collective purposes. A text can therefore be comparable to a painting in which a myriad of different colors get overlaid, leading to a distortion of the primary colors, such as a chromatic aberration, that interact with other colors. The translator has to wear specific glasses to be able to break away from her/his habits and examine with due attention what she/he has under the eyes. 
Once she/he has seen the whole picture - by means of the analysis of the context using the six extra-textual parameters - the translator has to proceed by parts. Moves are therefore relevant because they contribute to disentangle the picture; only then will the text make sense.

In order to better understand how the text is structured, and to go deeper into the intentions, the micro-linguistic elements analyzed are:

a) verb tense (boosting and hedging value);

b) approximators (promote vagueness);

c) negation (combines hedging and boosting functions);

d) adverbs and adjectives (boosting role);

e) passive voice (impersonalization promotes hedging while putting forward the invention object produces a boosting effect); and

f) modality: modal verbs (hedging) and verb modes (the indicative mode is preferred in patent abstracts because it is vague and ambiguous, unlike the subjunctive mode which hedges the discourse).

The patent, with its legal aspects, affects the way experts write because patent attorneys have the last word. A patent will not be written according to the same rules as a research article, a patient sheet, or a guide, even though these genres deal with the same discipline.

For instance, the translation of patents is a very specific skill. Even though there may be an infinite variety of things patented, the experienced translator understands that the situations in which patents are used are quite limited and very normative. There are only a limited number of social roles (patent lawyer, design engineer) concerned with patents and a limited number of social situations in which the texts are used. This extremely normative situation has been codified in a basic international patent structure (Lawson 1983). [...] Standardization is possible because there is a complete understanding of the purposes of the texts, the needs and background of their respective users, and the kinds of information to be transmitted. (Neubert and Shreve 1992: 86)

On this basis it may be inferred that terminology is only the tip of the iceberg and is not a solution for solving translation problems. So, what is important for patent translators? The rhetorical devices that take the form of outwardly petty microlinguistic elements are the elements that vouch for a successful communication. The translator has to absorb and adopt the conventional expressions in order to preserve the same objectives as the ones pursued by the author.

The freedom to innovate has its own constraints, in the sense that, if one were to flout generic conventions, it could potentially risk miscommunication or be noticed as odd by the established members of a professional community. (Bhatia 2000: 148)

For patent translators, it is very important to be aware of the rhetorical changes when rewriting - translating - the new text according to the text genre conventions so as not to shock the primary recipients of the target language community. The study makes clear that in Spanish and Chinese abstracts boosters prevail, while English and French are more likely to use 'neutral' rhetorical devices, even if in-depth analysis shows that there are also many ways of boosting. 


\section{Moves}

The same genre usually follows the same organizational structure (move). The most common moves are the ones studied by Swales (1990) and Dudley-Evans (1986). For research articles, the rhetoric model is IMRD (Introduction - Method - Results Discussion). Swales (1990) studied the Introduction and his study has revealed the following moves: 1 . establish a territory; 2 . establish a niche; and 3. occupy the niche. As for Dudley-Evans (1986), the Discussion section is divided into 3 moves: 1. introduction; 2. assessment of results; and 3. conclusions.

The relevance of describing the moves of a text contributes to a more appropriate textual interpretation; because reading is not a spontaneous act, it has to be organized and to follow a method, if translators want to be loyal to the original and produce acceptable texts for the recipients. It is to be said that the reading process will transform the text as it unavoidably implies interpretation. There is no objective reading act, as it is recognized for lawyers who seek the best interpretation of legal texts for their clients. Why should translation be an exception? As Bommier-Pincemin (1999) says the moving man, the maid and the carpenter do not analyze wooden furniture in the same way. The first will pay attention to furniture volume, the second will observe the space between the furniture and the floor to be vacuumed, and the third will notice the state of the wood. The same happens with texts. That is exactly what will happen with a patent office examiner, a competitor, and a translator when reading the same patent abstract! The same reality is not always understood in the same way by different persons.

Moreover, we have to bear in mind that translators are not the final recipients of any text and the author, when writing a text, never has the translator in mind. The latter then must find a pragmatic way to interpret what the text is trying to say in order to obey the author's intentions and the recipients' expectations.

Scientific exposition is structured in accordance with patterns of rhetorical organization and imposes, as such, conventions on members of the socio-professional community no matter what language they will use and what field they will focus on. Translators should not consider technical discourse as the gospel truth, but quite the opposite. The author's intentions are concealed in an apparently neutral discourse. Rhetoric is one of the arts of using language as a means to persuade. From ancient Greece to modern times, it has played a central part in training public speakers, i.e., politicians, and writers to move audiences to take action through discourse. A good reader must then learn to read and analyze a whole text, because reading is neither a spontaneous nor a natural act.

Moves become therefore useful guidance tools for translators when reading a text for the first time after having delimited the six extra-textual parameters. Move analysis will contribute to emphasize communicative and rhetorical purposes. The notions of objectivity, neutrality, universality of the discourse will be replaced by a more subtle communicative reality in which members of a community use genres as a persuasive weapon to 'stand up and be counted,' as well as be recognized in a discourse community. Private intentions merge with collective objectives and greatly complicate matters for the outsider translator who has to seek one way to the more adequate interpretation.

In the case of patents and patent abstracts, the identification of moves will help find answers to the following organizing questions: 
a) What technical field?

b) What has to be protected?

c) How to produce it?

Characteristics

Description of the procedure

d) What utility has the invention?

e) What advantages in comparison with prior art?

In other words, the patent abstract essentially consists of five moves: sector, object of the invention, method, utility, and advantages as the Results and Discussion section of this article suggests. Once this is known, the translator is able to make connection between the rhetorical devices used, as for example boosters and hedgers, and the text structure. The linguistic choices will then depend on the text genre, the rhetorical effect pursued by the author, the recipients' expectations, the text production context and circumstances; all this information will be very valuable for the translator and guide her/him in the maze of meanings and interpretations.

\section{Aims of the Study}

In a general way, the present study intends to provide a new vision of translation by enlarging the perspective, combining different points of view in Translation Studies, namely Functionalism, Skopos Theory, Textual Approaches, the School of Paris, taking a leaf out of other disciplines, such as sociology, psycholinguistics, pragmatics, rhetoric, discourse analysis, and adopting the most suitable elements to obtain the best GPS for the translator, who is an outsider of specific discourse communities.

The study is an answer to countless recurring questions raised during the dayto-day patent translator's work, i.e., what are the author's real intentions, how to find meaning, what is the best way to express an idea, how to convince the recipients, what are the conventions of this kind of text in the target language that have not been duly answered. Curiosity has led translators to open the Pandora's Box, get rid of intuition and automatisms and go beyond the beaten paths, because there is a consensus on the fact that firstly translators should not translate conventions; they already exist in each culture and community - may be different in the form -, and have to be used accordingly, and secondly they have to make sure the rhetorical effect is the one expected by the primary recipients of the text genre in a specific language.

Practice must be reconciled with theory; the practical problems originated from a narrowed vision of translation as a process of finding equivalences, however static, dynamic, and/or functional. Only theory could come to rescue. As García Yebra rightly points out "theory alone is sterile, and practice without theory, routine and blind."

La teoría sola es estéril, y la práctica sin teoría, rutinaria y ciega (García Yebra 1997: 16)

More precisely, the survey concerns a comparative study of a corpus of 200 patent abstracts in four languages (Chinese, Spanish, French and English) and four disciplines (medicine, chemistry, IT and telecommunications) and tackles the problem of translating patent conventions and the previously listed micro-linguistic elements. The analyzed texts are patent abstracts considered to represent a worldwide technical genre that exists in most cultures. It aims to provide valid and commonly 
accepted sentences and expressions used in patents in any of the four previously mentioned languages. To that end, we took advantage of the six extra-textual parameters that enable translators to glimpse the ins and outs of this particular communicative act, before proceeding both to a detailed micro-linguistic and rhetorical analysis of patent abstracts, and to the identification of rhetorical moves. This accurate investigation is somehow an autopsy of a patent abstract for the translator acting as a detective who will become an actor or what has previously been called a professional 'impostor' (Aragonés Lumeras 2007a).

In brief, the objectives are:

a) to provide evidence that text genre is a useful and valuable tool for Translation Studies and for translators;

b) to show that technical and scientific texts are neither objective nor neutral, but like any other human communicative act tend to persuade readers;

c) to prove that discipline does not play a central part in technical translation, shifting attention from terminology toward contextual and rhetorical aspects; and

d) to demonstrate that technical and scientific discourse, namely patents and patent abstracts use boosters to persuade the recipients of the utility of the invention, one of the three conditions of patentability.

\section{Methodology}

The first step was to select a corpus of patent abstracts. The criteria are:

1. All the texts pertain to the same genre 'patent abstract';

2. The publication date is to be comprised between 1999 and 2007;

3. The study is a synchronic one;

4. The texts must be originals and not translations, the languages being Chinese, Spanish, French and English regardless of the country of origin. For Spanish, most texts were selected from Spain, but a few came from Mexico and Cuba according to the importance of these countries in the patent applications. For French, texts come from France, as well as Switzerland and Belgium, and for English, most of the texts are from the US, but a few are from Canada and Australia. It is clear that for Chinese, all the texts are written in China and Taiwan.

5. The subject matter is restricted to medicine, chemistry, telecommunications and IT.

The corpus ${ }^{5}$ contains 200 texts, 50 patent abstracts for each language, and they have been selected according to four disciplines. Ten extra texts were added for each language and selected according to the following topics:

1. beverage preparation;

2. coal mine;

3. articles for smoking;

4. transgenic plants;

5. games;

6. firefighting;

7. drill;

8. waste treatment;

9. looms;

10. bicycle. 
The second step was to decide whether or not to use corpus linguistics. For technical reasons, namely the use of Chinese characters, the determination of rhetorical moves and the variety of analyzed languages, it was not possible to use any automated tool, such as Antconc. Therefore, a manual investigation was performed, using Word functions whenever possible, and the volume of the selected texts was reduced to 200 .

The third step involved choosing the most appropriate analysis for the purposes of the study: provide accurate data as well as a clear overview of the social communicative act and the human factors involved in it. An empirical study of the context of patent production adhering to the six extra-textual parameters was combined with a quantitative analysis. The qualitative study is based on the experience acquired as a professional patent translator, knowledge of the context, and extra-textual factors such as ceremony and conventions, institutions and their purposes, participants and their intentions. It aims at providing - for the translator - a general but helpful overview of the reasons and justifications for the specific communicative event. The quantitative analysis aims at identifying moves and linguistic resources according to two variables: discipline and language.

The quantitative analysis intends to identify the rhetorical moves - the five already established plus another one, because as the corpus shows, a few abstracts introduced another aspect (to be taken into consideration when identifying moves) putting the emphasis on the problem of the prior art and the proposed solution (the invention) - for each text, and to count the micro-linguistic elements for each abstract in each language. More precisely, each text was carefully read in order to recognize the structure of patent abstracts, the starting point of the analysis being to determine the object of the invention and how it is described. Special interest has been put on the three patentability conditions: novelty, inventive step, and utility.

The quantitative investigation is also comparative in the sense that the corpus contains texts written in four languages that deal with four different subject matters. The crucial question was to highlight how writers pertaining to different socio-professional communities write when they use the same text genre in order to clarify the role played by the discipline in the translation process, to emphasize the usefulness of genre for translators, as well as to identify the patent conventions for each language. In this way, the hypothesis that discipline does not play a leading role in translation contrary to one might think could be checked. The counting method is as follows: each move in each text regardless of the language and discipline was counted, and then the number of occurrences was divided into the number of texts to give the percentage of occurrences. For example, the move 'application sector' appeared in 50 texts, 50 (the number of texts in which this move appeared) was then divided into 200 (the total of texts), and the result was 25\%. Each micro-linguistic element was then submitted to the same process:
1. verb tense;
2. approximators;
3. negation;
4. adverbs and adjectives;
5. passive voice; and
6. modal verbs and verb modes. 
Finally, all the quantitative information collected during the investigation was translated into tables and charts during the fourth step so as to give a clearer vision of the current trend for each language and discipline.

\section{Extra- and intra-textual study: data and analysis}

First of all, it is worth indicating the different purposes and intentions of the author and other participants involved in the act of patenting so as to better understand the rationale and the text production context (qualitative analysis). A patent intends to:

1. prohibit others from making, using or selling the claimed invention;

2. ensure monopoly;

3. describe technically the object of the invention;

4. describe the invention with the largest legal coverage;

5. protect against piracy;

6. provide economic contribution; and

7. promote sales.

Patent abstracts, on the other hand, intend to:

1. provide technical information quickly;

2. help the specialist to search texts;

3. serve as a 'barometer' for the researcher;

4. indicate if the patent is worth reading;

5. provide a positive description of the invention; and

6. mislead competitors and lock research paths.

Before starting to analyze the intra-textual elements of patents and patent abstracts, it will be useful to set the stage giving an overview of the situational context when drafting patents and particularly patent abstracts. Translators, when dealing with patent abstracts, have to be aware of the ceremony. The ceremony in which participants are involved is the patent application. An inventor has invented a method and/or device and needs to seek protection for economic reasons. The formal conventions are imposed by text genre and are to be found in originals for each language, and should not be translated.

One of the difficulties in translating patent abstracts are the conventions. A common error is the proposed translation in French for 'patients in need thereof' 'patients en ayant besoin,' 'patients qui en ont besoin,' 'patients le nécessitant,' 'patients qui nécessitent le traitement.' When searching PATENTSCOPE , no occurrences were found for all these expressions in the original French patent abstracts. The French conventions impose the use of 'patients,' 'patients atteints de,' 'malades,' or 'personnes malades.' This is one example out of many, and the evidence seems to indicate that formal conventions are to be found in the target language originals.

Now that we know a little more on how to search information and how to identify formal conventions, we must focus on the institutions and their purposes, as well as the participants and their intentions. The institutions attempt to ensure the standardization of the documents. A patent abstract is part of the patent application that is filed in a national patent office, which is the only authority for granting a patent. 
Three ways can be used to gain protection:

1. nationally (through the national patent office);

2. regionally (through the EPO (European Patent Office) for instance); and

3. internationally (through the PCT (Patent Cooperation Treaty) Bureau at WIPO (World Intellectual Property Organization).

It is now clear that the institutions involved in the ceremony of patent application are the national or regional patent offices and WIPO. The patents are produced for the same communicative situation and the same communicative purposes, such as:

1. disclosing information related to the advantages of the patenting procedure;

2. filing the patent applications and checking their patentability;

3. answering all manner of questions emanating from the discursive communities;

4. smoothing the way of communication between the technical community and the legal one;

5. giving an incentive to technical development nationally and internationally; and

6. ensuring legal protection that leads to an economic benefit.

Finally, the individuals involved in the ceremony are numerous and colorful, to say the least. On the one hand, the socio-professional groups are formed by engineers, doctors, chemists, industrials, individuals, and so on, and by lawyers, patent attorneys on the other hand. These communities are not used to cooperate, the latter being the drafter of the patent and patent abstract, but not the inventor. In this hybrid genre, the participants of the ceremony - drafters and recipients such as patent attorney, inventor, engineer, and so on - have different backgrounds and do not share the same mutual knowledge. This situation implies ceremonial hybridization and textual mixture, especially when patent attorneys, who have a long legal tradition, have to find consensus with the inventor - the patent applicant, that is, the client - who comes from a scientific community. Their purposes diverge: the patent attorney intends to write a patent application with the best legal protection ensured by generic terms ('device for cooking and/or frying,', 'patients in need thereof,' etc.) and the legal conventions ('as way of example but not limited to,' 'in one embodiment,' 'those skilled in the art,' etc.).

As a result the written patent abstract often mixes legal discourse with technical discourse and makes the text harder to understand, particularly when the intentions of the authors are in conflict, as is the case with patents. It is worth citing here Philipp Mann from Mann Law Group ${ }^{6}$ who discusses the way things are expressed in patents:

The dirty little secret of patent prosecution is that clear statements in a patent application are anathema and the clear sign of a rookie drafter. The rules of thumb are legion: "never use the word 'invention."” Never say 'is." "Don't call a resistor a resistor - call it 'an impedance means' instead." The ironic joke is that the language used in patents is supposed to be that of persons "skilled in the art," but I have never once heard a real engineer ask for "an impedance means" or suggest replacing the "active element that preferably, but not necessarily, takes the form of a three-terminal semi-conductor or similar device." But the real blame for this lies not with patent prosecutors but with a judiciary that, on the one hand, claims it is fully capable of deciding highly technical cases, but on the other refuses to develop the skills needed to do so. [...] The courts simply don't require clarity and they punish it when it appears. 
Russ Krajec responds and explains why drafting a patent is such a difficult task:

One of the biggest reasons why patent drafters do not write comprehendible applications is because they have only a cursory understanding of the technology.

The patent drafter is asked to draft a document explaining the most advanced technology at that time. [...] to do a complete job, the attorney must understand the technology more thoroughly and with a better perspective than the inventor, who is by definition the most advanced person in the field. From this perspective, it is easy to understand why some patent applications are very vague and nearly incomprehensible.

Industrials, businessmen, attorneys, inventors, scientists, patent office substantive examiners, and laboratory researchers are all of them participants in the patent application ceremony and need to agree on which line to take because they must work together and pursue the same objectives, even if they do not share the same intentions. We have, as translators, to make allowances for this 'cultural' clash, as it creates a peculiar situation where patents are compulsory and imposed by the government on searchers and enterprises in order to make sure the results of investigations are shared.

This also means that there has been a large investment; this is why investors (companies) expect, in compensation, to be granted a protection and a 'monopoly' on the patented product and/or method, and want to make sure the invention is not totally disclosed to cut the ground from under the competitors' feet working on the same invention. As an illustrative example, here is a Spanish patent abstract:

El objeto principal de Ia invención consiste en el desarrollo de una solución higiénica y cómoda de manipulación y transporte de un líquido y de un producto pulverulento a mezclar con el líquido, así como se trata de que esta mezcla se pueda realizar de forma rápida y sencilla $[\ldots]$

Asimismo constituye un objeto de Ia invención que el envase forme un conjunto compacto e integral con un contenedor hermético que albergue el producto pulverulento y que sea de un solo uso para evitar Ia necesidad de higienizar el envase.

Why does the author choose to use such a long and indecipherable expression when referring to a very simple and obvious object of our day-to-day life? It seems to be a game, a kind of rebus; there must be a good reason for this. Once the translator has discerned and understood the six extra-textual parameters where and how, who and why, she/he will be able to decide if to keep this long sentence or to use the common work for the invention. What are we talking about? The response is not always in the text, as Philipp Mann and Russ Krujec have explained. Figures thus become the universal language used in science to achieve objectivity and universality. This may make the reader understand how tough it is for a patent translator to understand the text, not only because of specialized and technical terms, but also for the very peculiar way of writing patent abstracts; in a nutshell, the conventions. Surprisingly, despite the fact that the patent employs household words understandable to the common man, it is still challenging for the reader, especially in the case of the translator, to grasp the meaning. 
A simple glimpse at the drawing provides the answer to the translator (Figure 1).

FIGURE 1

Snapshot of the figure accompanying a patent application ${ }^{7}$

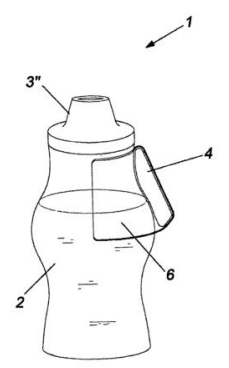

As simple as that: a baby bottle. Now considering the fact that patents are confidential ${ }^{8}$ documents that, in the case of the World Intellectual Property Organization (WIPO), cannot be sent to translation agencies, we can imagine how difficult it is to translate patent abstracts. If the translator receives only the abstract, it would be extremely difficult to understand the text without figures, description or specifications.

As Reed (2008) said in San Francisco (ATA Annual Conference, November 2007) and confirmed in his article, the tenses used in patents are very important because they give information on the patent procedure. The examples play a critical part and serve two purposes: they provide information on how to make and use the invention and they prove the utility of the invention. However, in some cases it is not possible "to conduct actual experiments and the patent drafter must resort to using hypothetical or prophetic examples." The tenses then play the leading role: real examples are written in the past tense, while hypothetical examples are written in the present or future tenses. As the study indicates, past tense is seldom used and present tense has top billing. As a result, it can be deduced that most of the patents are not demonstrated to be working. The translator has to be aware of the rhetorical importance of tenses to make sure she/he respects the author's intentions and the institutional communicative purposes.

Now that the contextual scene is set, the problem of text organization will be tackled. After a long investigation, the results of the study suggest that patent abstracts are written according to six moves. The rhetorical moves, regardless of discipline or language, for patent abstracts are as follows (Aragonés Lumeras 2009: 195, 197, 199-200):

1. application sector $(25 \%)$;

2. problem-solution (10\%);

3. object of invention (90\%);

4. technical characteristics $(90 \%)$;

5. utility (40\%); and

6. advantages (40\%).

The study shows how the moves are distributed according to discipline and language, respectively. Given the results, it can be seen that the 'object' move appears almost always in the whole corpus, the same can be said for its 'characteristics.' As for the 'utility' move, it appears throughout all the text (4 texts have this move out 
of 10). The 'advantages' move slightly varies throughout the discipline, and is more present in medicine and less used in chemistry. We have to keep in mind that medicine is a very competitive field, and drugs are commercialized products, while chemistry is taken for a 'hard science' and is part of the preparation of drugs; there is no need therefore to put emphasis on the advantages of chemistry, while medicine has to point up the quality of the invention. No significant variation is observed with the 'application' and 'problem-solution' moves.

If we now consider how the same moves are represented in the texts classified according to the language, we can conclude that no significant change is observed. As shown in graphics (Aragonés Lumeras 2009: 196-201), the 'object' and 'characteristics' moves are almost omnipresent in each language according to the same proportion. The 'utility' and 'advantages' moves follow the same pattern, even if Chinese is prone to use advantages when describing an invention, while French and English do not give priority to the emphasizing move. The 'problem-solution' move is more common in Chinese, and this may indicate that Chinese writers favor an intensifying rhetorical effect when writing a patent abstract. Although there are a few variations, the quantitative data suggest that neither discipline nor language influence the writer's choices. This evidence seems to indicate that it is genre that imposes its own constraints on drafters, and not discipline or language.

Past tenses were used once in Spanish, French and English patent abstracts in the 'characteristics' move, except for French where they were used in the 'advantages' move (Aragonés Lumeras 2009: 206-208). This means that patent abstracts offer poor evidence of the reliability of the invention. Furthermore, present tense, which is the common tense, is used to confuse the reader and convince her/him without indicating whether the invention has been tested and works.

Aragonés Lumeras' study (Aragonés Lumeras 2009: 208-210) gives an overview of how often approximators are used. Spanish and English favor approximators in IT, while Chinese stands up to doing so. French gives priority to approximators in the chemistry industry, followed by Spanish language. It must therefore be recognized that Chinese dislikes approximators, that is to say, Chinese does not want to be too vague, unlike Spanish, French and English. Again, precision does not seem to be a specific feature in patent abstracts. The analysis showed the importance of 'o,' 'sea' in Spanish, '或' in Chinese, 'ou,' 'soit' in French, and 'or,' 'either' in English in the chemical industry. This data suggests that, even if the Chemistry field seems to prefer vagueness, there is no relationship between discipline and vagueness. The inventions tend to list ingredients to prepare a compound and add "or" so as not to disclose the whole invention and provide different embodiments of the invention. Vagueness is the privileged form of patent abstract genre, which opposes preconceived notions of clarity and precision.

Another linguistic means studied in Aragonés Lumeras (2009: 210-211) was negation and its rhetorical functions: boosting the advantages and at the same time hedging the criticism against the prior art. The numerical trend shows that negation is more frequently used in medicine and less used in chemistry. It has to be said here that medicine, as well as IT and Telecommunications (especially for English and Spanish), prefer to use boosters.

The occurrences of negation in discipline and language suggest medicine is the technical field in which negation is more commonly used, especially for Spanish 
abstracts. In English, the frequency of use is almost the same in medicine, telecommunications and IT, with no occurrences in chemistry (Aragonés 2009: 211). The boosting effect of negation seems therefore to play a crucial part in medicine whatever the language. There is strong evidence that medicine is a sector where boosting is given priority, because it constitutes the discipline which is most influenced by competitors working on similar inventions. They must therefore be quicker than other researchers.

Medicine is the sector where the use of emphasizing adverbs and adjectives is favored (Aragonés Lumeras 2009: 211-213), followed by chemistry and IT. Not surprisingly, Spanish tops the group with 44 boosting adjectives and adverbs, as it seems to be a language prone to intensifying the discourse in patent abstracts. English comes second with 33 counts, followed by French (29) and Chinese (23). Again, the competitive situation in the field of medicine and IT may explain the importance of promoting information to convince the recipients, obtain a patent and commercialize the invention.

In the table showing the frequency of passive voice in patent abstracts according to language and discipline (Aragonés Lumeras 2009: 214), the curve for the 'characteristics' move reveals that regardless of language, the passive voice is preferred, especially for English and French. Data show that Chinese and Spanish do not generally use passive voice in medicine and chemistry, while in the telecommunications and IT sectors it is given priority. Unlike English, Chinese is not a language that privileges passive voice. It is also worth noting that French, in patent abstracts, tends to favor passive voice in comparison with common French.

Spanish has two ways of expressing passive voice: a) to be + participial, and b) the reflexive. The recount of occurrences in Spanish tends to indicate that patent abstracts prioritize the use of reflexives, while for French it is the other way around. In the case of Chinese, we have three options for expressing passive voice: a) 被, 所, and 由. Although 被 is favored in telecommunications, there are no real variations in the recounting. 由 (by) is the element that introduces the person or object originating the situation or action, and may thus be taken for a more explicit passive voice.

Whereas Edison's patents (1869) were introduced by the first person pronoun and signed by Edison himself, patents have evolved and attention has shifted from the inventor to the invention so as to give more objectivity to the discourse. English and French prefer passive voice. These results suggest that, even if French does not tend in the common language to favor passive voice, the patent abstract genre modifies the grammatical uses to achieve different purposes or because it is under the influence of English. Passive voice can thus be considered a rhetorical device for giving priority to the object of the invention, the writer disappears in order to put a slant on the object and give the illusion that the technical discourse in patents is objective and neutral.

What might strike at first glance is the number of occurrences in English in the telecommunications field, in chemistry (for French) and telecommunications (for Chinese). Note, however, that 'can' and 'may' were counted 30 times in four patent abstracts. 'Can' has several meanings whatever the language, amongst which two are of interest for this study. The first one expresses eventuality and possibility and can be taken for a hedging device, reducing the author's commitment to what is claimed, 
while the second one has a boosting effect because it refers to the capacity and ability of the invented product or method. 'Can' also means 'to be able to' and places the importance on capacity, this is why in French 'permettre,' 'susceptible' and 'apte' and Spanish 'permitir' and 'apto' are commonly used in patent abstracts. In this particular case, these expressions present a boosting effect even if a superficial reading can lead to the impression that their rhetorical effect is neutral. This might be one of the reasons for using this kind of expression, as previously stated, i.e., that the author tries to persuade of the utility of the invention while pretending to be neutral and unbiased. As for verb modes, indicative is the common mode in every language and discipline, even if Spanish, French and English patent abstracts seldom use the subjunctive, this mode being imposed by the grammar of the language.

Finally, modality (Aragonés Lumeras 2009: 218) is frequently used in Chinese and English, especially through the use of '可 (以), '能 (够)' as well as 'can' and 'may.' It is interesting to point out here that Chinese patent abstractors employ boosting language even if they employ modality resources. This seems to discredit the common view shared by searchers concerning the function of modal auxiliaries. Modality is not only a way of expressing lack of commitment and politeness, it can also emphasize the discourse.

To summarize, it is worthwhile to first address several issues concerning the limits of this investigation. Combining two variables - language and discipline - four languages (Chinese, Spanish, French and English) as well as four disciplines (medicine, chemistry, telecommunications and IT) has hindered the study because most of it was manually conducted. Moreover, the large extent of this investigation has made analysis of translation behavior impossible, although the size of the corpus was limited and the conclusions should therefore be corroborated by future studies. This is why the numerical information must be analyzed with caution and should be validated with further studies on patents and/or patent abstracts. (Aragonés Lumeras 2009: 231). The results can be summarized as follows:

TABLE 1

Table summarizing the quantitative results of the investigation

\begin{tabular}{|l|l|l|l|l|l|}
\hline Verb tense & Approximator & Negation & $\begin{array}{l}\text { Boosting } \\
\text { adverb and } \\
\text { adjective }\end{array}$ & Passive voice & Modality \\
\hline $\begin{array}{l}\text { The usual } \\
\text { tense is } \\
\text { present }\end{array}$ & $\begin{array}{l}\text { More frequent } \\
\text { in chemistry } \\
\text { and IT fields }\end{array}$ & $\begin{array}{l}\text { More frequent } \\
\text { in medicine } \\
(2.76 \% \text { ) and } \\
\text { Spanish, } \\
\text { telecom } \\
(1.88 \% \text { ) IT } \\
(1.67 \% \text { ) and } \\
\text { Chemistry } \\
(0.47 \%) .\end{array}$ & $\begin{array}{l}\text { Less used in } \\
\text { French }\end{array}$ & $\begin{array}{l}\text { Occurs } \\
\text { normally in } \\
\text { the } \\
\text { Characteristics } \\
\text { move }\end{array}$ & $\begin{array}{l}\text { Modal verbs: } \\
\text { 'may' and 'can' } \\
\text { are often used } \\
\text { in chemistry } \\
\text { and English, } \\
\text { followed by } \\
\text { Chinese (less } \\
\text { common in } \\
\text { French) }\end{array}$ \\
\hline $\begin{array}{l}\text { Future } \\
\text { indicates } \\
\text { hypothetical } \\
\text { realization }\end{array}$ & $\begin{array}{l}\text { Favored in } \\
\text { French \& }\end{array}$ & $\begin{array}{l}\text { English } \\
\text { Spanish }\end{array}$ & English & More often in & \\
\hline
\end{tabular}




\begin{tabular}{|c|c|c|c|}
\hline $\begin{array}{l}\text { Past indicates } \\
\text { that the } \\
\text { experience has } \\
\text { been } \\
\text { conducted }\end{array}$ & $\begin{array}{l}\text { 'At least' is } \\
\text { commonly } \\
\text { used in French } \\
\text { and Chemistry }\end{array}$ & $\begin{array}{l}\text { Spanish } \\
\text { prefers to use } \\
\text { reflexive 'se.' } \\
\text { French and } \\
\text { Chinese prefer } \\
\text { active voice }\end{array}$ & $\begin{array}{l}\text { Verb modes: } \\
\text { indicative is } \\
\text { the common } \\
\text { mode; } \\
\text { subjunctive } \\
\text { and } \\
\text { conditional } \\
\text { are seldom } \\
\text { employed }\end{array}$ \\
\hline
\end{tabular}

In other words, moves are understood as rhetorical tools associated with genre and reveal the following communicative purposes (Aragonés Lumeras 2009: 222-223):

1. To describe technically the invention without divulging it (maintain vagueness and ambiguity);

2. To stress novelty; and

3. To promote the invention so as to attract investment to implement it.

Most common moves are 'object' (90\%) and 'characteristics' (90\%), followed by 'utility' (40\%) and 'advantages' (40\%), 'sector of application' (25\%), and 'problemsolution' (10\%), being less common. Thus, the homogeneous structure of patent abstracts helps recognize the genre, achieve the collective objectives, and point up the author's intentions, i.e., promoting and selling the invention. In this sense, it is interesting to note that promotional genres use similar rhetorical tricks since the crucial aim is to sell the product and make money.

That said, Chinese patent abstracts employ the 'utility' and 'advantages' moves to emphasize interest, whereas for French and English vagueness is privileged. Reckoning with the findings of several rhetorical studies (Vihla 1999, Varttala 2001, Chien 2002, Oliver del Olmo 2004, Martín-Martín 2005, Feng 2006, Van Bonn and Swales 2007, and Feak and Swales 2007) of academic and scientific genres, the advantages are not presented cautiously. On the contrary, present tense is used to increase reality without intensifying and promoting ambiguity. English seems to pitch on politeness and no commitment. Approximation is not chosen by Chinese abstractors, but is used in the French chemical industry (6.05\%) and the English and Spanish IT sectors $(6.83 \%$, and $5.79 \%$ ).

Negation (often used in 'characteristics' and 'advantages') plays exclusively a boosting function, regardless of language and discipline. Mitigation and intensification combine to achieve communicative purposes that overpower objectivity in the technical discourse. However, criticizing the prior art with negation is also a way to provide proof of the utility of the invention and make the tone more promoting. Again, Chinese and Spanish abstracts obey the following principle: emphasize the discourse in order to promote the object, but mitigate it with the negative form. We should keep in mind that China and Spain (as well as Latin American countries) do not have a long tradition of patenting; although initially present in Spain in the $17^{\text {th }}$ century, it was then pushed into the background by historical circumstances.

Rhetoric seems to be the 'strategy' the observer uses to express a point of view, to persuade the audience, and to (re)act after a text has been published without disclosing the whole invention. It is thus legitimate to infer that the specificity of each ceremony is the determining factor for properly drafting a text. Now, what the student 
needs in order to learn how to write is to read and become familiar with paralle ${ }^{10}$ texts. Genre may then be considered a GPS for drafters, abstractors, patent attorneys, translators, etc. Hyland and Milton (2000) center their attention on the pragmatic value of genre:

A writer may use a 'hedge,' or tentativeness marker, not only to express doubt and reduce personal accountability for a statement, but also to gain acceptance for a claim by demonstrating sensitivity to the views of readers and by seeking to involve them in a dialogue. (Hyland and Milton 1999: 148)

Patent abstract translators often face dissatisfaction regarding the methods employed to solve recurring translational problems. The solution is not (always) to be found in terminology, but derives from the inadequacy of language use in a particular ceremony. Technical drafting becomes a solution for translators, but its implementation should not be left to luck - it instead must be related to text genre and the six studied extra-textual parameters. Hyland and Milton's point of view has not been proven wrong. They stress the relevance of contextualizing a text or a genre for language learners. The same is valid for translators:

Much of the learner's inadequate language education has been based on the practice of memorizing lists of such decontextualised phrases, which generally seem to have been arrived at without recourse to authentic NS [native speaker] use [...] Language learners need access to the entire lexical and syntactic breadth of semantic target language, but they also need guidance in order to recognize the semantic and pragmatic contexts of the target genre [...] Language learners often do not have adequate interactive guidance to help them make linguistic choices. (Hyland and Milton 1999: 159)

Two statements can be made: translators and patent abstractors can benefit from rhetorical moves in order to communicate suitably with the recipients' expectations as well as improve the drafting skills identifying the acceptable conventions for the ceremony.

\section{Conclusions}

The present study constitutes a novel approach to analyzing translation according to text genre, in this particular case patent abstract. Although it would be difficult to determine the real scope of the six extra-textual parameters (ceremony-convention, institutions-communicative purposes, participants-intentions) used in this investigation, the analysis shows promising results both in qualitative and quantitative terms regarding the two hypotheses. According to these findings, the specific objectives seem to be met:

a) Text genre is a useful tool to analyze text production context and rhetorical effects;

b) Technical and scientific texts are neither objective nor neutral;

c) The discipline does not play a significant role in the rhetorical (hedging and boosting) and linguistic means;

d) Patents and patent abstracts use boosters to persuade the recipients of the utility of the invention.

It seems therefore to be confirmed that discipline is not a decisive factor that affects the drafting of patent abstracts, and text genre establishes itself as the leader. 
This article also presents a new reality to translators as a pedagogical alternative that can help future translators (students and professionals) become aware of how our representations shape the ways in which we see translation work. Hence, understanding translation as being mediated by different contextual factors (ceremonyconvention, institutions-communicative purposes, and participants-intentions) can assist translators and professors face new challenges and, more particularly, make decisions more easily so as to meet ceremonial requirements and audience expectations.

Each genre has its peculiar way of providing information and has to be recognized by its users. Indeed genres rely on our being able to recognize them and to some degree "understand the meanings they instantiate within the systems of which they are part." (Bazerman 1994: 81)

The study suggests that translators and teachers should focus on text genre in order to solve recurring translation problems since it has been demonstrated that most linguistic choices rely on specific contextual situations and depend on the ability (to be developed) to identify text genre to ensure that the translator, even if she/he is an outsider, ${ }^{11}$ has understood the reasons why the exchange of information has taken the form it has.

On the one hand, Chinese and Spanish patent abstractors seem to share an interest in boosting resources and they mitigate this rhetorical choice by using hedging devices, while on the other hand their French and English counterparts have chosen to hedge the manner in which information is provided and favor vagueness. Three motives may explain these fundamental differences: 1) The long tradition of patenting in Anglo-Saxon and French speaking countries has given pride of place to the object of the invention, that is emphasizing the subject matter in order to conceal the real intentions (not disclosing the invention) while objectifying the utility and validity of the invention; 2) Both inventor and IP agent favor vagueness to provide better protection; 3) French and English are languages that commonly recur to "empty" formulas to be polite and respectful.

\section{NOTES}

1. Six extra-textual parameters (ceremony-conventions, institutions-purposes, participants-intentions) have been used to train translation students in a Master's Degree Program at ETI (École de Traduction et d'Interprétation, Geneva), and make them aware that meaning is not inherent to a text, but is the result of the analysis of the six extra-textual parameters. These students now feel ready to translate any text genre, even patents.

2. Gentt (Textual Genre for Translation) <www.gentt.uji.es $>$.

3. 'Friendly' should be understood here as acceptable but not shocking; convincing but not aggressive; conventional but not unexpected, etc.

4. The micro-linguistic elements that act as boosters have been highlighted.

5. The 200 patent abstracts can be found in Aragonés 2009; source for English, French and Spanish abstracts: PATENTSCOPE ${ }^{\circledR}$ WIPO's Gateway to Patent Services and Activities, (Updated last: September 2009) <www.wipo.int/patentscope/en/>, and for Chinese abstracts中国专利数据SIPO homepage <http://search.cnpat.com.cn/Search/CN/>, (Updated last: September 2009).

6. IPLitigation Blog (Updated Last: 11 February 2009). Visited 10 June 2009, <www.iplitigationblog. com>.

7. WO/2008/129092. <http://www.wipo.int/pctdb/en/fetch.jsp?LANG=ENG\&DBSELECT=PCT\&SE RVER_TYPE=19-00\&SORT $=11269907-K E Y \& T Y P E \_F I E L D=256 \& I D B=0 \& I D O C=1693561 \& C=$ 00\&ELEMENT_SET $=$ BASICHTML-ENG\&RESULT $=2 \&$ TOTAL $=10 \& S T A R T=1 \& D I S P=25 \& F O R$ $\mathrm{M}=$ SEP-0/HITNUM,B-ALL,DP,MC,AN,PA,AB-ALL\&SEARCH_IA=ES2008000224\&QUERY=\% 22biber\%26\%23xF3\%3bn\%22>, visited on 25 March 2010. 
8. Confidentiality is a sensitive subject because if translators want to be socially recognized as members of a discourse community, as well as lawyers and doctors, we have to make every effort to find social recognition (by means of examinations or certifications) for professional translators who have to deal with confidential and secret information in their day-to-day work.

9. Milton and Hyland (2000: 151) rightly point out in their comparative study that 'will' indicates that something will happen with a certain degree of confidence unlike 'would.' 'For example, 'will' occurs twice as frequently in the NS data. As both forms can refer to present or future probabilities, the distributions suggest that, at least as far as this device is concerned, NNS writers tend toward confident prediction while native speakers prefer to express themselves more tentatively."

10. Parallel texts are documents written in different languages pertaining to the same text genre. The translator has to obey the rules followed by students in the sciences: read many texts from the same genre in the target language so as to get used to the formal conventions and draft a new text with this genre knowledge.

11. Berkenkotter and Huckin (1995) employ this term to refer to young students who have not yet taken part in an information exchanging ceremony, must become familiar with the discourse community and have little knowledge of the social and formal conventions.

\section{REFERENCES}

Aragonés Lumeras, Maite (2007a): Tradición, traición, traducción. Intercambios. 11(2):16-19.

Aragonés Lumeras, Maite (2007b): Translating Patents: Translative Strategies. Proceedings of $48^{\text {th }}$ ATA Annual Conference. 327-334.

Aragonés Lumeras, Maite (2008a): Meaning: The Philosopher's Stone of the Alchemist Translator? Translation Journal. 12(3):1-4.

Aragonés Lumeras, Maite (2008b): Convenciones formales de patentes. Puntoycoma. 109:6-7.

Aragonés Lumeras, Maite (2008c): El traductor ante la ceremonia de solicitud de patentes. Actas del Congreso Mundial de Traducción Especializada. (Congreso Internacional de Traducción Especializada, Havana, Cuba, 8-13 December 2008). Paris: Unión Latina. 36-40.

Aragonés Lumeras, Maite (2009): Estudio descriptivo multilingüe del resumen de patente: aspectos contextuales y retóricos. Bern: Peter Lang.

BAzERMAN, Charles (1994): Systems of genres and the enactment of social intentions. In: Aviva Freedman and Peter Medway, eds. Genre and the New Rhetoric. London and New York: Taylor \& Francis, 79-101.

Berkenkotter, Carol and Huckin, Thomas N. (1995): Genre Knowledge in Disciplinary Communication. Cognition/Culture/Power. New Jersey: Lawrence Erlbaum Associates.

Berkenkotter, Carol, Huckin, Thomas N. and Ackermann, John (1989): Social Context and Socially Constructed Texts: The Initiation of a Graduate Student into a Writing Research Community. In: Charles BAzerman and James PARAdis, eds. Textual Dynamics of the Professions: Historical and Contemporary Studies of Writing in Professional Communities. Madison: University of Wisconsin. 191-215.

BнатіA, Vijay (2000): Genres in conflict. In: Anna Trosborg, ed. Analyzing Professional Genres. Amsterdam/Philadelphia: John Benjamins, 147-162.

Bommier-Pincement, Bénédicte (1999): Diffusion ciblée automatique d'informations. Conception et mise en ouvre d'une linguistique textuelle pour la caractérisation des destinataires et des documents. Doctoral thesis, unpublished. Paris: Université Paris-Sorbonne (Paris IV).

Chien, Hui-Ling (2002): The Understanding of and Attitude toward Hedging Devices in English Medical Journals by Taiwanese Medical Professionals. Doctoral thesis, unpublished. Kaohsiung: National Kaohsiung University of Science and Technology.

Dudley-Evans (1986): Genre analysis: An investigation of the introduction and discussion sections of MSC dissertations. In: Malcolm Coulthard, ed. Talking about Text. Discourse Analysis Monographs. University of Birmingham: English Language Research.

FEAK, Christine B. and Swales, John (2007): Constructing English-language Journal Article Abstracts. In: III Simposio Internacional sobre Linguagem, Cultura e Sociedade realizado na Universidade Federal de Santa Maria. 
FENG, Haiying (2006): A corpus-based study of research grant proposal abstracts. Perspectives: Working Papers in English and Communication. 17(1):1-24.

Freadman, Anne (1994): Anyone For Tennis? In: Aviva Freedman and Peter Medway, eds. Genre and the New Rhetoric. London and New York: Taylor \& Francis, 43-65.

García IzQuierdo, Isabel, ed. (2005): El género textual y la traducción. Reflexiones teóricas y aplicaciones pedagógicas. Bern: Peter Lang.

García Yebra, Valentín (1997): Teoría y Práctica de la Traducción. Vol. 2. $3^{\text {rd }}$ ed. Madrid: Gredos.

Hyland, Ken and Milton, John (1999): Assertions in students' academic essays: A comparison of English NS and NNS student writers. In: Roger Berry, Barry Asker and Ken Hyland, eds. Language Analysis, Description and Pedagogy. Hong-Kong: Language Center HKUST, 147-161.

Hyland, Ken (2000): Disciplinary discourses: Social Interactions in Academic Writing. Harlow: Longman.

Martín-Martín, Pedro (2005): The Rhetoric of the Abstract in English and Spanish Scientific Discourse. A Cross-Cultural Genre-Analytic Approach. Bern: Peter Lang.

Neubert, Albrecht and Shreve, Gregory M. (1992): Translation as Text. Kent, Ohio and London: The Kent State University Press.

Nord, Christiane (1997): A Functional Typology of Translation. In: Anna Trosborg, ed. Text Typology and Translation. Amsterdam/Philadelphia: John Benjamins, 43-67.

Oliver del Olmo, Sonia (2004): Análisis contrastivo español/inglés de la atenuación retórica en el discurso médico. El artículo de investigación y el caso clínico. Doctoral thesis, unpublished. Barcelona: Universitat Pompeu Fabra.

ReED, T. Dave (2008): International Patenting and the Translator: An Essential Partnership. The ATA Chronicle. 27(6):16-19.

SAger, Juan C. (1997): Text Types and Translation. In: Anna Trosborg, ed. Text Typology and Translation. Amsterdam/Philadelphia: John Benjamins, 25-41.

Salager-Meyer, Françoise (1994): Hedges and Textual Communicative Function in Medical English Written Discours. English for Specific Purposes. 13:149-170.

Swales, John M. (1990): English in Academic and Research Settings. $9^{\text {th }}$ ed. Cambridge: Cambridge University Press.

Toury, Gideon (1995): Descriptive Translation Studies and beyond. Amsterdam/Philadelphia: John Benjamins Publishing Company.

VAN Bonn, Sarah and Swales, John (2007): English and French journal abstracts in the languages sciences: Three exploratory studies. Journal of English for Academic Purposes. 6(2):93-108.

Varttala, Teppo (2001): Hedging in Scientifically Oriented Discourse. Exploring Variation According to Discipline and Intended Audience. Doctoral thesis, unpublished. Finland: University of Tampereen Yliopisto.

Vihla, Minna (1999): Medical Writing. Modality in Focus. Amsterdam and Atlanta: Rodopi. Widdowson, H. G. (1979): Explorations in Applied Linguistics. Oxford: Oxford University Press. 